\title{
THE EFFECTIVENESS OF PARENTING MANAGEMENT TO IMPROVE PARENTS EMPOWERMENT (Case Study of Children's Play Group in Bani Shaleh Bandung)
}

\author{
Nandang Rukanda \\ IKIP Siliwangi \\ nandangsae@gmail.com
}

\begin{abstract}
This study aims to describe the process of implementing parenting programs for learners' parents in Bani Shaleh Playing Group and application of learning outcomes. The research method used is descriptive qualitative, with the main data collection technique is done through observation and interview, while documentation study is used to strengthen research depth. Subjects were conducted to one of Baya Shaleh Play Group heads, 2 educators, and 5 respondents who were parents of students. The results showed that the process of organizing parenting was successfully implemented by the respondents who showed the ability to establish children when they play. Parents did not intervene in their children's activities but tend to act as observers and facilitators of their activities. Recommendations are formulated for each child play group to develop parenting activities on a regular basis, while parents should actively participate in this program and all parties need to provide full support not only in the form of attention but also in the form of financial support.
\end{abstract}

Keywords: Parenting Program, Society Empowerment, Children Independence.

\section{INTRODUCTION}

Education according to Law no. 20 Year 2003 on Sisdiknas (Ps 1: 1) is a conscious and planned effort to create an atmosphere of learning in the learning process so that learners actively develop their potential to have religious spiritual strength, self-control, personality, noble moral intelligence, and the necessary skills himself, society, nation and religion. Education does not end at the end of school education, but it is a lifelong process, occurring during the entire life span of the individual. Long life education includes formal, non-formal and informal education.

Indeed the goal of lifelong education is to form learning to be and the learning society is interpreted as follows:

a. Life-long education is to form a person to be himself (learning to be). He learns to think, learns to be productive citizens, learns to behave and behaves as a good citizen even includes many deeper things, such as the process of self-discovery and achieving awareness of self-abilities and weaknesses, ultimately aimed at empowerment, independence and improved quality of life.

b. The goal of lifelong education is to form the learning community. In the community there are educational institutions and non-educational institutions, which potentially and tangibly provide education services to the people who need them. Institutions (non-education) in the community function as educational providers and not just as users of educational outcomes. 
Non-Formal Education is an education / learning process that occurs outside the education and school system (formal). In it there is regular and directed communication, wherein a person obtains information, knowledge, parenting or guidance in accordance with age and necessities of life with the aim of developing skill levels, attitudes and values, with an arrangement of time structure, place, sources and parents of learners who are diverse, flexible, but still directed.

Informal education held in the family sphere plays a major role in preparing the lifelong learning process that spans the life span of a person. In addition to learning, habituation and role model are also obtained, as a formal education partner means that Non-formal Education can serve as substitution, complement, and supplements and can bridge into the world of work. Non-formal education held in the community at the institution that helps learners in the community so always learn about the values, attitudes, knowledge and functional skills needed to actualize themselves and to develop the community and the nation with always oriented to the future of life progress.

Non-formal education has a relationship with lifelong education that has the same goal that is to survive and sustain life, and to improve the quality of life. In the process of organizing early childhood education, there is actually a component that indirectly becomes the support of its interests namely a group of parents of students, who have entitled to gain knowledge development in an effort to maintain the existence of life. This is where the role of non-school education through parenting methods is needed to complement the shortcomings of their participation in formal education.

Parenting is an educational effort undertaken by the community by utilizing the resources available in the family and the environment in the form of independent learning activities. in general the purpose of parenting program, is to invite parents to jointly provide the best for their children. While specifically the purpose of parenting program development are:

1. Improve knowledge and skills of parents in carrying out care, nurturing, and education of children within the family itself with the foundation of the basics of good character.

2. Bringing interests and desires between the family and the school to synchronize both so that character education developed in early childhood institutions can be followed up in the family environment.

3. Linking between school programs and home programs.

The main programs of non-formal education developed in Indonesia, both governmentrun, and the community are the Early Childhood Education Program (PAUD), in which there are units of play groups (Kober). In such institutions gathered parents who intend to provide coaching and guidance to their children through the mediation of educators play groups, so that children can grow and develop optimally.

PAUD institutions have institutional and learning programs that are not all in harmony with the habits that occur in the family environment. With the parenting program is actually intended to alignment of mutually reinforcing children coaching between coaching through the family environment and early childhood education. 
Parenting programs given to parents will affect parenting of children. Parenting patterns are patterns of behavior that parents apply to children and are relatively consistent over time. Parenting is the best way parents can take in educating their children as a manifestation of a sense of responsibility to their children (Mansur, 2005: 350).

In the field level in general, parents who put their children in PAUD Institution shows have not used their children to be independent. Parents still tend not to release their children in learning. Researchers will review the parenting program on Kober Bani Shaleh UPT PK PNFI VIII Bandung to see the application of knowledge obtained from the program against his son.

\section{LITERATURE REVIEW}

\section{Long Life Education for Learners' Parents}

According to Knapler and kropley that: "... lifelong education has been defined as a set of organizational, administrative, methodological, and procedural measures ..." and "lifelong learning describes the habit of continuously learning throughout life, a mode of behavior". In the meantime, Sutaryat said that lifelong education refers to a series of extrinsic factors, oriented supplying (supply), by identifying the needs and the means.

The purpose of lifelong education is in order to improve the quality of life, namely that individuals in society can learn and should continue to learn and continually seek to erode ignorance and fatalism.

The 1945 Constitution mandates efforts to educate the life of the nation through the implementation of the national education system regulated by the Law. One of the objectives of education is expected to improve the quality of Indonesian human beings in realizing an advanced, just and prosperous society based on Pancasila and the 1945 Constitution which enables its citizens to develop themselves as fully Indonesians. With the enactment of the Law of the Republic of Indonesia Number 2 of 1989 on the National Education System states that Out of School Education is an integrated part that supports the implementation of the function of education by developing skills and improving the quality of life and dignity in realizing national goals or community development, and Non-formal education.

Non-formal Education itself is a form of education whose purpose is to provide education services to all citizens and is entitled to education throughout life in accordance with the development of the demands of the times.

In Law no. 20 In 2003, the national education system consists of three lines: formal, non-formal, and informal education. Non-formal education units in the National Education System, including, study groups, courses, parenting, ta'lim assemblies, community learning centers, and similar educational units. Into similar educational units it includes; play group, nursery, training house, learning activity studio, study center, hermitage, upgrading, counseling center, training center, scout, education service center through other mass media. 
According to Sudjana, H. D (2004: 1), Non-Formal education is any conscious, deliberate, organized and planned effort that aims to assist learners in developing themselves so that human beings who love to learn, able to improve the standard of living, and participate in social activities.

Organizers in the PAUD program can come from government agencies and the public. The organizer must prepare facilities and infrastructure and other equipment to support the success of the PAUD program. The surrounding community strongly supports the sustainability of the ECD program. This community support as an effort to participate in the success of PAUD program implementation. The family is very influential on the sustainability of early childhood education. The pattern of education in the family acts as the primary and first education in the growth and development of children.

At the level of the field, still the low understanding of the importance of early childhood for the development of children so that the empowerment of parents of students becomes something very important. The role of the community in the implementation of the program early childhood is:

1. Community as a motivator, the community as a motivator of the implementation of early childhood, especially in the local environment.

2. The community as a facilitator, i.e. the community participates in facilitating the implementation of early childhood in order not to rely on government assistance (to be self-help community).

3. Community as a companion, the community as a partner in the implementation of early childhood so that the program can run on community support.

\section{Anticipating Global Cultural Change}

Globalization has influenced all aspects of life both toward attitudes, behaviors, even the way we speak. The development of science and technology is very influential on the development of children who must be balanced by the ability of their parents. Some of the factors influenced among modern society through the culture of globalization are as follows:

a. Lack of public awareness of the values of eastern culture, and choosing to opt for a more modern, up-to-date, and practical foreign culture.

b. Cultural learning in schools is poorly taught. Many primary and secondary educational institutions have considered that learning about local culture is no longer relevant.

The outdating indigenous culture of Indonesia as a state identity is felt when the culture of Indonesia is contaminated with western culture, so this country lost direction in balancing the progress of the times. The old man who was a person who is highly respected by children, nowadays parents have become just friends for children. Culture care for the environment is increasingly fading. The fading of the habit has an impact on the moral of the nation's children, as well as on the environment. So much of the polluted nature makes the beauty of the environment has diminished. 
Maintaining Indonesian culture is an obligation for all the people of Indonesia. Never let globalization shift the existence of Indonesian culture so that melunturkan values and norms of the Indonesian nation.

\section{Parenting Interests on Learners' Parents}

Parenting program is very important for parents because this program is a school for parents to be smart parents in nurturing, and educate their babies. By following the program parents can learn how to cope with children wisely and appropriately.

Education is not only for children but education is also important for parents. Education for parents is a Parenting Program where parents will be educated and educated to be ideal parents. In this Parenting program parents will learn and mentor, speakers or fellow participants by listening to speakers and mentors who review a problem or sharing or exchange ideas between participants or can consult with mentors or speakers in meetings being held or outside meetings.

In the context of Early Childhood Education (PAUD), parenting education is based on the importance of family connectivity with educational institutions and includes the role of the family in the interest of the child. The purpose of parenting itself, according to Susilo Rahardjo, is to raise parents' awareness of children's education, improve parent's knowledge and skills in carrying out the treatment, and to meet the interests and wishes of the family and school.

\section{Andragogy Method}

The andragogy method is a method of learning aimed at adults. This term is often encountered in both the non-formal education process (out-of-school education) and in the formal education learning process. The function of educators in andragogy is only as a facilitator, not patronizing, so that the relationship between educators and learners (students, parents of learners) is more multi-communication. (Knowles, 1970). Therefore, andragogy is a form of learning that is able to produce learning goals (graduates) who can direct themselves and able to become educators for themselves. With these advantages, andragogy becomes the foundation in the non-formal education process. This happens because the non-formal education of the learning formula is directed to the target conditions that emphasize the improvement of life, the provision of skills and the ability to solve the problems experienced especially in life and target life in the midst of society.

Andragogy comes from the Greek "andra and agogos". Andra means adult and Agogos means leading or guiding, so that andragogy can be interpreted as a science of how to guide adults in the learning process as Knowles thought in Srinivasan (1977) states that: andragogy as the art and science to help adult a learner.

Hatton (1997: 38-40) introduces the concept of DAMN in the interests of adult learning as shown in the diagram below: 


\section{a. Desire to learn}

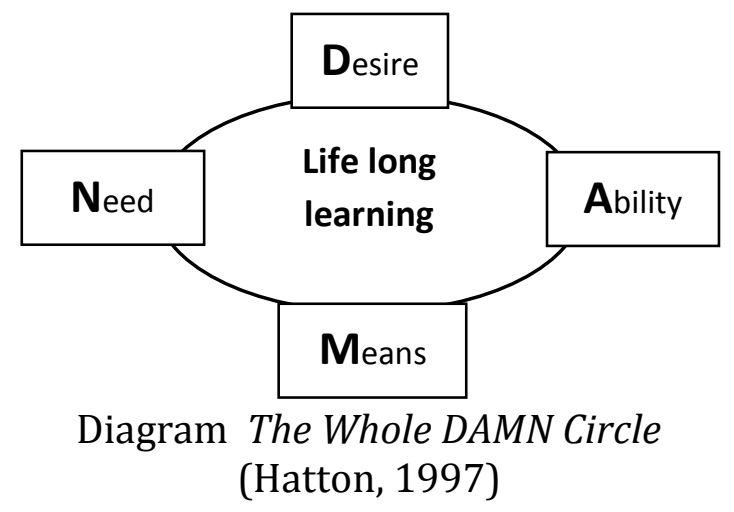

Adults in learning tend to investigate and search for what drives their curiosity and intellect. The application of the principle of andragogy in the learning process becomes important, because the goals (learners, parents, students, students) will never be independent in determining what they want to learn, how to learn it and with what strategies are used to learn something and sometimes not learn nicely. Miller and Dollard affirm that: "Learning takes place when something, something not to forget something. This, learning in this view requires the interplay of four essential aspects: the perception (the noticing aspect), responding (the doing aspect) and reward or reinforcement (the receiving aspect). If any motivation were set to zero, for example, would be disputed "(Miller and Dollard, 1973: 134).

\section{b. Ability to learn}

In a learning process, learning objectives need to be encouraged to understand the meaningfulness of the learning tasks, so that the target is on the ability and increase mastery of the steps of learning activities significantly. Delor (1996) and Soedijarto (1997) recommend four pillars of the process of education and learning, namely: learning to know, learning to do, learning to be and learning to live together.

\section{c. Means to learn}

This concept provides support that adults are ready to learn something because of the level of development that they have to face in their role as workers, parents or leaders of the organization. This has implications for learning materials in a particular parenting. In this case the learning materials adapted to the needs in accordance with its social role to form the goals of education forming learning to know, learning to do, learning to be, and learning to live together for the perpetrators.

\section{d. Need to learn}

The need to study in adults is a tendency to have a learning orientation centered on problem-solving problems (problem centered orientatin). This is because learning for adults seems to be a need to deal with the problems faced in everyday life, especially in relation to the functions and social role of adults.

\section{RESEARCH METHODS}

The research used qualitative method that essentially aimed to describe and analyze various findings on the topic under study. Qualitative research is holistic and emphasizes the process, so the relationship between the variables in the object studied 
is more interactive is the interplay; it is not known which independent and dependent variables.

This research was conducted in Early Childhood Education Play Group Baya Shaleh Instituion, Bandung. The data source in this research is one of Baya Shaleh Play Group Heads, 2 educators, and 5 parents of students. The main techniques used by the authors in collecting research data is interview (interview), observation (observation), study documentation.

Researchers conducted data analysis during the study conducted. Activities undertaken by researchers, except with the process of compilation, data classification, and ultimately understanding of the meaning contained therein.

Data analysis at the time of research is done by recording field data, conducting member check to research subject, doing triangulation, and make improvement of analysis. After from the field, from the data collected then done:

1. Data reduction, ie summarizing field reports, recording data, calcifying and finding trends that arise according to the focus of research;

2. Shows the data so that the data relationship one with the other data becomes clear and mutually form a unified whole, comparing as well as analyzing in more depth to obtain its meaning;

3. Drawing conclusions.

\section{RESEARCH RESULT AND DISCUSSION \\ Research Result}

\section{General Description of Research Subject}

Kober Bani Shaleh UPT PK PNFI VIII Bandung is one of the management of Early Childhood Education program which is based on the formation of children in a religious nationalist, especially to form students who have akhlakul karimah (very noble attitude). This requires parents to be empowered in exemplary for their children.

The vision of Kober Bani Shaleh is the center of natural and religious learning builds the intellectual foundation of the nation towards a healthy generation, smart and morals, while its mission is:

1. Building a generation of quality nations

2. Shaping learners in maturity on Cognition, affection and psychomotor to enter school education.

3. Establish learners on religious adherence correctly.

4. Shaping learners on a polite personality

The parenting arrangement for parents of students is held every Thursday at the third week, at 09.00 - 11.00 WIB along with learning hours of students. The learning model used is based on andragogy theory approach.

Parenting materials provided with regard to the ability of parents in the care and nurture of children, which involves: 
1. Understanding the role as educating

2. Understanding techniques to communicate with children.

3. Understanding the importance of independence in children

4. Parenting as a parent.

\section{Planning Aspect}

Parenting program plan actually pay attention to the condition of the parent's needs in providing guidance to children with themes tailored to the needs of upto date. Based on the results of the study, it is known that the planning of parenting is direct direction from the head of Bani Shaleh. Specifically the activities undertaken in carrying out the function of planning the program of guidance to parents with the target of activities is the parents of children learners.

The general purpose of this parenting is to provide the knowledge, skills and attitudes of professionalism of parents in fostering children. The parents of the students are expected to be able to educate children properly, able to synergize the pattern of upbringing with the institutionalized and performed.

The results of interviews conducted with the head Kober Bani Shaleh can be seen that the results to be achieved in the parenting program is to form parents who are personable and skilled in fostering their children in the family environment that can be synchronized with the guidance that is done through the institutions of the group play Bani

Shaleh.

The parents of the students are targeted to understand how to educate children, able to communicate well, able to make children independent and able to realize the good suritauladan.

\section{Aspects of Implementation}

The implementation of parenting is held every month on Thursday of week three, at 09.00 - 11.00 WIB. The approach used in organizing parenting is andragogy and participation. While the method is adapted to the material raised. Meanwhile, the learning techniques used are: lectures, frequently asked questions, discussions and demonstrations.

The implementation of the parenting program took place in the learning space of the learners Kober Bani Shaleh with the provision of LCD facilities. Implementation of the parenting program with the theme of child self-reliance delivered through lectures, questions and answers and videos of children's independence. The process of implementing the parenting program includes opening activities, giving materials by resource persons, question and answer and closing.

Based on the theory of andragogy especially in the identification of parenting needs, formulating parenting goals, parenting programming and evaluation, it can be assumed that parents are aware of the important goals to be achieved. The learning process in parenting includes objectives, materials, methods, techniques, media, learning and evaluation activities as well as learning resources and parents of learners. Implementation of a learning activity, including parenting is a process of transforming knowledge, attitudes and skills from learning resources to parents of learners. It is 
evident that the implementation of parenting is done effectively and efficiently because it is in accordance with the scheduled time.

At the time of this parenting program, parents of learners are welcome to provide questions or the outpouring of the heart so that interactive dioalog occurs. Parenting parenting learners are expected to practice accurately the results of the parenting learning process. Furthermore, the parents of the protégé are assisted to join the group member of one parenting group of parents activists of early childhood education students.

\section{DISCUSSION}

The learning process of adults positions the participants as people who have their own knowledge and experience, and become informants. Facilitators play a role in facilitating and mendinamisasi process of learning. The methods applied in the delivery of materials include, brain storming, lectures, and interactive discussions. Malcolm Knowless in developing the concept of andragogy, developed four principal assumptions as follows:

\section{a. Self concept}

The assumption is that adult self-concept is self-sufficient. Independence is shown by adults with self-determining ability (self-determination), self-directed. Adults also have deep psychological needs in order to generally become self-sustaining, albeit in certain situations. This has implications for the implementation of the exercise, especially with regard to climate and learning atmosphere and diagnosis of needs and parenting planning process.

\section{b. Role of experience}

Adults, on their way, have experienced and accumulated life experiences. Therefore, in parenting technology or adult learning there is a decrease in the use of transmitting techniques such as those employed in conventional parenting and to further develop experiential techniques. This has implications for the selection and use of methods and techniques of importance for more experimental learning, such as group discussions, opinion ventures, laboratory work, field schools, practical work, and the like.

\section{c. Readiness to learn}

The assumption that adults are ready to learn something because of the level of development; in that they have to face in their role as workers, parents or organizational leaders. This has implications for learning materials in a particular parenting. In this case of course learning materials need to be tailored to the needs in accordance with its social role.

\section{d. Learning orientation}

The assumption is that adults have a tendency to have a learning orientation centered on solving problems encountered (problem centered orientation). This is because learning for adults seems to be a need to deal with the problems faced in everyday life, especially in relation to the function and social role of adults. 
In Kober Bani Shaleh, guidance is made to the parents of the students to gain knowledge about the meaning of education, communication techniques with children, independence and ethics behave as parents.

Parents guardian children are directed to be able to provide education to their children so that they can be independent for the sake of the realization of a good future. Not only limited directed to the increase of knowledge, but intended that parents can provide coaching children in harmony with education at home. In accordance with the disclosed by Mukhtar Latif et al (2013: 260) that parent education is education provided in order to know and apply the right education in educating young children, especially when children are in the family environment with their parents at home. It is intended that the activities at home do not conflict with the activities at school (PAUD).

Planning in the parenting program is done by all managers and educators, both in determining the schedule of activities, program materials, and infrastructure to support the implementation of parenting programs to run optimally.

Implementation of parenting program runs in accordance with the planning that has been made. Implementation of parenting program with the theme of training children's independence in Kober Bani Shaleh includes opening activities, speeches, giving materials by resource persons, question and answer and interactive dialogue, role playing and closing.

The evaluation of the parenting program was carried out by a deliberation method among the administrators of Kober Bani Shaleh to know the shortcomings and advantages of the programs that have been implemented so as to determine the next step.

Implementation of learning outcomes parenting program is done by way of assistance to parents in the care of their children. One form indicates that the parenting participants have applied their learning outcomes when accompanying their children to play, the parents do not intervene in their activities but rather tend to act as observers and facilitators of their activities. This is in accordance with Akram Misbah Uthman (2005: 109) that we must give understanding to our children that various behaviors based on awareness, responsible nature and in accordance with the surrounding social conditions are the key to his acceptance by friends - her friend. Under these circumstances the role of parents remains an important factor in developing a social system and personality system for children, including in early childhood (Akhyadi dan Mulyono, 2018).

\section{CONCLUSIONS AND RECOMMENDATIONS Conclusion}

1. The process of implementing parenting program for the child's parent learners held every month on Thursday the third week, with the same time on the activity activity of children sports $09.00-11.00$ WIB from at the time place in the learning space Kober Bani Shaleh learners. The process of implementing a parenting program begins with a plan initiated by the head of Kober. Implementation of the parenting program begins with opening, core events, frequently asked questions and 
interactive dialogue, ending with cover. Evaluation of the parenting program is done by discussing the implementation process covering all activities from beginning to end of activity.

2. The application of parents parenting results to their children is monitored by Kober Bani Shaleh educators to measure how far the effectiveness of the success of the parenting program is applied in the personality of the parents of the students. The proof of the success of this program is demonstrated by the ability of parents to establish children who are shown when accompanying their children to play, the parents do not intervene in their activities but rather tend to act as observers and facilitators of their activities

\section{Suggestion}

1. The parenting program shows the activities that are important for every play group, so it needs to be developed in every institution of early childhood education unit.

2. The implementation of the parenting program should be carried out routinely, scheduled and disciplined implementation so that the results will be effective and measurable.

3. Parents should understand the importance of the parenting program and follow it actively.

4. Parenting programs are proven to have beneficial impacts on the community, especially those related to the improvement of parenting skills in educating the child. Therefore, it needs the opinion and the support from all parties.

\section{REFERENCES}

Abdulhak, I., (1995), Media Pendidikan Suatu Pengantar, Pusat Pelayanan dan Pengembangan Media Pendidikan IKIP Bandung.

Akhyadi, A. S. dan Mulyono, D. 2018. Program Parenting dalam Meningkatkan Kualitas Pendidikan Keluarga. Jurnal Abdimas Siliwangi, Volume 1 (1), hal. 1-8.

Akram Misbah Utsman (2005). 25 Kiat Membentuk Anak Hebat. Jakarta: Gema Insani Press.

Luluk Asmawati dkk (2008). Pengelolaan Kegiatan Pengembangan Anak Usia Dini. Jakarta : Universitas Terbuka.

Mukhtar Latif dkk (2013).Orientasi Baru Pendidikan Anak Usia Dini. PT Fajar Interpratama Mandiri.

Hasan, ES., (2008), Reoptimalisasi Manajemen Pendidikan Luar Sekolah dalam Konstalasi Teoritis dan Praktis, Jurusan Pendidikan Luar Sekolah, Fakultas Ilmu Pendidikan, UPI, Bandung

Hikmat, H., (2006), Strategi Pemberdayaan Masyarakat, (Edisi Revisi), Penerbit Humaniora, Bandung.

Kindervatter, S., (1979), Non Formal Education as an Empowering Process, Amherst: Centre for International and Education

Nasution S., (1996), Metode Penelitian Naturalistik Kualitatif, Tarsito, Bandung

Safuri, M., (2005), Evaluasi Program. Pembelajaran dan Pemberdayaan Masyarakat. Yayasan Pengkajian Pendidikan Non Formal Indonesia Y-PIN Indonesia. 
Sudjana, HD., (2004) Manajemen Program Pendidikan, untuk Pendidikan NonFormal dan Pengembangan Sumber Daya Manusia, Falah Production, Bandung. 